\title{
FAKTOR RISIKO LINGKUNGAN DAN PERILAKU YANG BERHUBUNGAN DENGAN KEJADIAN PENYAKIT DEMAM BERDARAH DENGUE (DBD) DI WILAYAH KERJA PUSKESMAS PURWOKERTO SELATAN KABUPATEN BANYUMAS TAHUN 2016
}

\author{
Belliya Yulis Rahmadani'), M. Choiroel Anwar'), Hari Rudijanto I.W ${ }^{3)}$ \\ Jurusan Kesehatan Lingkungan, Politeknik Kesehatan Kemenkes Semarang, \\ Jl.Raya Baturaden KM 12 Purwokerto, Indonesia
}

\begin{abstract}
Abstrak
Demam berdarah dengue (DBD) merupakan penyakit yang disebabkan oleh virus dengue yang ditularkan dari orang ke orang melalui gigitan nyamuk Aedes aegypti. Puskesmas Purwokerto Selatan merupakan daerah dengan jumlah kasus DBD tertinggi di wilayah Kabupaten Banyumas, pada tahun 2015 berjumlah 92 kasus.. Tujuan dari penelitian ini adalah untuk mengetahui faktor risiko lingkungan dan perilaku dengan kejadian penyakit DBD di Kabupaten Banyumas. Metode penelitian ini adalah penelitian analitik observasional dengan desain studi Case Control, jumlah sampel kasus sejumlah 34 kasus dan 34 kontrol. Variabel yang diteliti meliputi keberadaan jentik, jenis TPA, warna TPA, keberadaan tanaman sekitar rumah, ventilasi, mobilitas, kebiasaan menggantung pakaian, kebiasaan tidur siang, dan kebiasaan menggunakan repellent. Analisis yang digunakan yaitu Data yang diperoleh dianalisis ke dalam analisis univariat, bivariat dengan uji Chi-square $\left(X^{2}\right)$ dan multivariat dengan menggunakan uji regresi logistik. Hasil analisis bivariat menunjukkan variabel yang berhubungan dengan kejadian DBD yaitu variabel kebiasaan menggantung pakaian $(p=0,033 ;$ OR $=4,942)$. Hasil analisis multivariat diketahui variabel yang berpengaruh besar/ dominan berhubungan dengan kejadian penyakit DBD adalah variabel kebiasaan menggantung pakaian $(p=0,011)$. Simpulan penelitian ini adalah variabel yang berhubungan dengan kejadian penyakit DBD yaitu variabel kebiasaan menggantung pakaian. Variabel yang berpengaruh dominan adalah variabel kebiasaan menggantung pakaian. Disarankan bagi pihak puskesmas Purwokerto Selatan dan kader kesehatan untuk Meningkatkan promosi kesehatan kepada masyarakat tentang cara mencegah DBD .
\end{abstract}

Kata Kunci : Lingkungan, perilaku, Demam berdarah dengue (DBD)

\begin{abstract}
Risk Factors of Environment and Behavior which Correlate with Dengue Haemorrhagic Fever (DHF) Case in Puskesmas Area of South Purwokerto Banyumas Regency year 2016. Dengue Haemorrhagic fever (DHF) is a disease caused by dengue virus which is transmitted from one person to others through Aedes aegypti mosquitos. Puskesmas South Purwokerto is a place with the highest cases in Banyumas Regency, in 2015 was 92 cases. The purpose of this research is to find out risk factors of environment and behavior with DBD disease case in Banyumas Regency. The method used in this research is analytic observational design study Case Control, the case sample was 34 cases and 34 controls. Variable examined are the existence of mosquito larva, the kind of TPA, the color of TPA, the existence of plats around the house, ventilation, mobility, the habit of hanging clothes, the habit of nap, and the habit of using repellent. Analysis used in the research is Data which is analyzed into univariate analysis, bivariate used Chi-square $\left(X^{2}\right)$ test and multivariate used logistic regression test. The result of this research shows that the variable correlated with DBD case is the habit of hanging clothes variable $(p=0,033 ; O R=4,942)$. The result of multivariate analysis is found that the variable which has the biggest influenceldominant correlated with DBD case is the habit of hanging clothes variable $(p=0,011)$. The conclusion of this research is that variable correlated with DBD disease case is the habit of hanging clothes variable. The variable which has the biggest influence is the habit of hanging clothes variable. The researcher suggests to Puskesmas South Purwokerto and Puskesmas health volunteer to improve health promotion to people about how to prevent DBD.
\end{abstract}

Key Words : Environment, Behavior, Dengue Haemorrhagic fever (Deman Berdarah Dengue/DBD)

\footnotetext{
1) E-mail: belliyaayulis@yahoo.co.id

2) E-mail: irul1960@yahoo.co.id

3) E-mail: hariokey2000@yahoo.com
} 


\section{Pendahuluan}

Menurut Undang - Undang Republik Indonesia Nomor 36 Tahun 2009 tentang Kesehatan pasal 162 menyebutkan bahwa upaya kesehatan lingkungan ditujukan untuk mewujudkan kualitas lingkungan yang sehat, baik fisik, kimia, biologi, maupun sosial serta memungkinkan setiap orang mencapai derajat kesehatan setinggi - tingginya. Dalam rangka mewujudkan derajat kesehatan, maka pencegahan penularan penyakit wajib dilakukan oleh masyarakat termasuk penderita penyakit menular melalui perilaku hidup bersih dan sehat.

Faktor lingkungan yang berpengaruh terhadap penyebaran kasus DBD antara lain: faktor lingkungan fisik (kepadatan rumah, keberadaan kontainer, suhu, kelembaban), faktor lingkungan biologi (keberadaan tanaman hias, pekarangan, keberadaan jentik nyamuk), faktor lingkungan sosial (pendidikan, pekerjaan, perilaku penghasilan, mobilitas penduduk, kepadatan penduduk, PSN) (Dinata, 2011).

Berdasarkan hasil penelitian sebelumnya, yang dilakukan oleh Dardjito dkk pada peneltian beberapa faktor risiko yang berpengaruh pada kejadian penyakit DBD di Kabupaten Banyumas tahun 2008, bahwa faktor perilaku yang mendukung terjadinya DBD, yaitu kebiasaan menggantung pakaian dan kebiasaan menggunakan obat anti nyamuk.

Puskesmas Purwokerto Selatan merupakan daerah dengan jumlah kasus DBD tertinggi di wilayah Kabupaten Banyumas, pada tahun 2014 terjadi 67 kasus dengan IR 85,3 per 100.000 penduduk, sedangkan pada tahun 2015 terjadi peningkatan menjadi 92 kasus dengan Inciden Rate (IR) sebesar 120,16 per 100.000 penduduk dan CFR 1,04\% (profiil kesehatan puskesmas purwokerto selatan, 2015).

Tujuan dari penelitian ini adalah untuk mengetahui faktor risiko lingkungan dan perilaku dengan kejadian penyakit DBD di Wilayah Kerja Puskesmas Purwokerto Selatan Kabupaten Banyumas.

\section{Bahan dan Metode}

Metode penelitian ini adalah penelitian analitik observasional dengan desain studi Case Control, jumlah sampel kasus sejumlah 34 kasus dan 34 kontrol, total minimal adalah 68 sampel. Variabel yang diteliti meliputi keberadaan jentik, jenis TPA, warna TPA, keberadaan tanaman sekitar rumah, ventilasi, mobilitas, kebiasaan menggantung pakaian, kebiasaan tidur siang, dan kebiasaan menggunakan repellent.

\section{Hasil dan Pembahasan}

\section{Gambaran Umum Wilayah}

Puskesmas Purwokerto Selatan berada di wilayah Kecamatan Purwokerto Selatan . Wilayah
Puskesmas Purwokerto Selatan terdiri dari 7 kelurahan, dengan Luas wilayah Kecamatan Purwokerto Selatan 13,75 Km².

Berdasarkan data dari Kecamatan Purwokerto Selatan pada akhir tahun 2015, Jumlah penduduk di wilayah Puskesmas Purwokerto Selatan sebanyak 76.559 jiwa yang terdiri dari 37.943 laki-laki $(49.56 \%)$ dan 38.616 perempuan $(50.44 \%)$ tergabung dalam 20.600 rumah tangga / KK.

\section{Gambaran Kasus DBD}

Tabel 1 Gambaran Kasus DBD di wilayah kerja Puskesmas Purwokerto Selatan

\begin{tabular}{ccccc}
\hline No & Tahun & $\begin{array}{c}\text { Jumlah } \\
\text { Penduduk }\end{array}$ & $\begin{array}{c}\text { Juml } \\
\text { Kasus }\end{array}$ & $\begin{array}{c}\text { IR per } \\
1000\end{array}$ \\
\hline 1 & 2011 & 72.353 & 67 & 0,93 \\
2 & 2012 & 73.266 & 31 & 0,42 \\
3 & 2013 & 73.643 & 92 & 1,24 \\
4 & 2014 & 74.609 & 67 & 0,9 \\
5 & 2015 & 76.559 & 92 & 1,2 \\
\hline
\end{tabular}

Berdasarkan Tabel diatas menunjukan bahwa kasus DBD tertinggi terjadi pada tahun 2013 dengan 92 kasus ( $I R=1,24$ ) dan tahun 2015 dengan 92 kasus ( $\mathrm{IR}=1,2$ ), dan kasus DBD terendah terjadi pada tahun 2012 dengan 31 kasus $(\mathrm{IR}=0,42)$.

\section{Analisis Univariat \\ Keberadaan jentik pada kontainer}

Tabel 2 menunjukan bahwa rumah responden yang ditemukan jentik sebanyak 10 rumah $(29,4 \%)$ dan yang tidak ada jentik 24 rumah (70,6\%). Pada kelompok kontrol Rumah responden yang ditemukan jentik sebanyak 3 rumah $(8,8 \%)$ dan yang tidak ada jentik 31 rumah (91,2\%).

\section{Jenis TPA}

Kontainer jenis TPA ditemukan pada 27 $(79,4 \%)$ rumah dan kontainer jenis non TPA sebanyak 7 rumah ( 20,6 \% ). Pada kelompok kontrol kontainer jenis TPA ditemukan pada 32 ( 94,1 \%) rumah dan kontainer jenis non TPA sebanyak 2 rumah ( $5,9 \%)$.

\section{Warna TPA}

TPA dengan warna gelap ditemukan pada 21 rumah $(61,8 \%)$ dan TPA dengan warna terang sebanyak 13 rumah ( 38,2 \%). Pada kelompok kontrol TPA dengan warna gelap ditemukan pada 18 rumah ( 52,9 \%) dan TPA dengan warna terang sebanyak 16 rumah $(47,1 \%)$.

\section{Keberadaan tanaman sekitar rumah}

Responden yang mempunyai tanaman sekitar rumah sebanyak 27 rumah ( 79,4 \%) dan responden yang tidak memunyai tanaman sekitar rumah sebanyak 7 rumah (20,6 \%). Pada kelompok kontrol Responden yang mempunyai tanaman sekitar rumah sebanyak 28 rumah ( $82,4 \%)$ dan responden yang tidak memunyai tanaman sekitar rumah sebanyak 6 rumah $(17,6 \%)$ 
Tabel 2 Analisis Univariat

\begin{tabular}{|c|c|c|c|c|c|c|}
\hline \multirow{2}{*}{ No } & \multirow{2}{*}{ Variabel } & \multirow{2}{*}{ Katagori } & \multicolumn{4}{|c|}{ Kelompok } \\
\hline & & & Kasus & $\%$ & Kontrol & $\%$ \\
\hline \multirow{2}{*}{1} & \multirow{2}{*}{ Keberadaan Jentik } & Ada & 10 & 29,4 & 3 & 8,8 \\
\hline & & Tidak & 24 & 70,6 & 31 & 91,2 \\
\hline \multirow{2}{*}{2} & \multirow{2}{*}{ Jenis TPA } & TPA & 27 & 79,4 & 32 & 94,1 \\
\hline & & Non TPA & 7 & 20,6 & 2 & 5,9 \\
\hline \multirow{2}{*}{3} & \multirow{2}{*}{ Warna TPA } & Gelap & 21 & 61,8 & 18 & 52,9 \\
\hline & & Terang & 13 & 38,2 & 16 & 47,1 \\
\hline \multirow{2}{*}{4} & \multirow{2}{*}{ Keberadaan tanaman sekitar rumah } & Ada & 27 & 79,4 & 28 & 82,4 \\
\hline & & Tidak & 7 & 20,6 & 6 & 17,6 \\
\hline \multirow{2}{*}{5} & \multirow[t]{2}{*}{ Ventilasi } & Tidak ada kawat kassa & 30 & 88,2 & 28 & 82,4 \\
\hline & & Ada kawat kassa & 4 & 11,8 & 6 & 17,6 \\
\hline \multirow{2}{*}{6} & \multirow{3}{*}{ Mobilitas } & Ada & 15 & 44,1 & 12 & 32,3 \\
\hline & & Tidak & 19 & 55,9 & 22 & 64,7 \\
\hline \multirow[b]{2}{*}{7} & & Biasa menggantung & 31 & 91,2 & 23 & 67,6 \\
\hline & Kebiasaan menggantung pakaian & Tidak biasa menggantung & 3 & 8,8 & 11 & $(32,4$ \\
\hline \multirow{2}{*}{8.} & \multirow{2}{*}{ Kebiasaan tidur siang } & Biasa tidur siang & 18 & 52,9 & 12 & 35,3 \\
\hline & & Tidak biasa tidur siang & 16 & 47,1 & 22 & 64,7 \\
\hline \multirow{2}{*}{9} & \multirow{2}{*}{ Kebiasaan menggunakan repellent } & Tidak biasa & 27 & 79,4 & 22 & 64,7 \\
\hline & & Biasa & 7 & 20,6 & 12 & 35,3 \\
\hline
\end{tabular}

\section{Ventilasi}

Rumah responden yang tidak memasang kawat kasa pada ventilasi sebanyak 30 rumah $(88,2 \%)$ dan yang memasang kawat kasa sebanyak 4 rumah (11,8\%). Pada kelompok kontrol Rumah responden yang tidak memasang kawat kasa pada ventilasi sebanyak 38 rumah ( $82,4 \%$ ) dan yang memasang kawat kasa sebanyak 6 rumah $(17,6 \%)$.

Mobilitas

Responden yang melakukan mobilitas sebanyak 15 orang $(44,1 \%)$ dan yang tidak melakukan mobilitas sebanyak 19 orang $(55,9 \%)$. Pada kelompok kontrol Responden yang melakukan mobilitas sebanyak 12 orang $(35,3 \%)$ dan yang tidak melakukan mobilitas sebanyak 22 orang $(64,7 \%)$.

\section{Kebiasaan menggantung pakaian}

Responden yang biasa menggantung pakaian sebanyak 31 orang $(91,2 \%)$ dan yang tidak biasa menggantung pakaian yaitu 3 orang $(8,8 \%)$. Pada kelompok kontrol Responden yang biasa menggantung pakaian sebanyak 23 orang ( $67,6 \%)$ dan yang tidak biasa menggantung pakaian yaitu 11 orang $(32,4 \%)$.

\section{Kebiasaan tidur siang}

Responden yang biasa tidur siang sebanyak 18 orang $(52,9 \%)$ dan tidak biasa tidur siang sebanyak 16 orang $(47,1 \%)$. Pada kelompok kontrol Responden yang biasa tidur siang sebanyak 12 orang $(35,3 \%)$ dan tidak biasa tidur siang sebanyak 22 orang $(64,7 \%)$.

\section{Kebiasaan menggunakan repellent}

Responden yang tidak biasa menggunakan obat anti nyamuk sebanyak 27 rumah $(79,4 \%$ dan yang biasa menggunakan repellent sebanyak 7 rumah (20,9\%). Pada kelompok kontrol Responden yang tidak biasa menggunakan obat anti nyamuk sebanyak 22 rumah $(64,7 \%)$ dan yang biasa menggunakan repelent sebanyak 12 rumah $(35,3 \%)$.

\section{Analisis Bivariat \\ Hubungan keberadaan jentik dengan kejadian DBD}

Tabel 3 menunjukan bahwa hasil uji statistik dengan menggunakan Chi-square, diperoleh $p$ value 0,062 , karena $p$ value $>0,05$ maka Ho diterima, artinya tidak ada hubungan yang signifikan antara variabel keberadaan jentik pada kontainer dengan kejadian DBD di Wilayah Kerja Puskesmas Purwokerto Selatan Kabupaten Banyumas Tahun 2016.Walaupun tidak berhubungan tetapi selisihnya sedikit dengan Nilai Odd Ratio $(O R)=4,306(95 \% \mathrm{CI}=1,066$ 17,389), menunjukan bahwa rumah responden yang positif jentik mempunyai risiko 4,306 kali lebih besar menderita DBD dari pada rumah responden yang tidak ada ditemukan jentik.

Menurut Sembel (2009, h. 63) nyamuk Ae. aegypti berbiak dalam air - air bersih yang tertampung dalam kontainer - kontainer bekas seperti botol - botol plastik, kaleng - kaleng bekas, ban mobil bekas, tempurung, bak - bak air penampungan yang terbuka, bambu - bambu pagar, tempurung kelapa, pelepah kelapa, kulit kulit buah sepeti kulit buah rambutan, vas - vas bunga segar yang berisi air

Tidak adanya hubungan antara keberadaan jentik dengan kejadian DBD ini karena responden sudah ada yang menyadari tentang penyakit DBD dan dibeberapa wilayah sudah melakukan PSN dan pernah dilakukan PSN serentak di Kabupaten Banyumas sehingga pada saat survei berlangsung keberadaan jentik pada tempat penampungan air berkurang tetapi tidak maksimal.

Penelitian ini sejalan dengan penelitian yang dilakukan oleh Sofia, dkk (2014) diperoleh $\mathrm{p}=0,402$ artiya tidak ada hubungan antara keberadaan jentik pada kontainer dengan kejadian DBD. 
Tabel 3 Analisis Bivariat

\begin{tabular}{clcccc}
\hline No & \multicolumn{1}{c}{ Faktor risiko } & P & OR & CI & Ket \\
\hline 1 & Keberadaan jentik & 0,062 & 4,306 & $1,066-17,289$ & Tidak ada hubungan \\
2 & Jenis TPA & 0,15 & 0,241 & $0,46-1,259$ & Tidak ada hubungan \\
3 & Warna TPA & 0,624 & 1,436 & $0,547-3,770$ & Tidak ada hubungan \\
& Keberadaan tanaman sekitar rumah & 1,00 & 1,210 & $0,360-4,065$ & Tidak ada hubungan \\
& & & & & \\
5 & Ventilasi & 0,734 & 1,607 & $0,410-6,229$ & Tidak ada hubungan \\
6 & Mobilitas & 0,620 & 1,447 & $0,545-3,842$ & Tidak ada hubungan \\
7 & Kebiasaan menggantung pakaian & 0,033 & 4,942 & $1,236-19,760$ & Ada hubungan \\
& & & & & \\
8 & Kebiasaan tidur siang & 0,222 & 2,063 & $0,779-5,461$ & Tidak ada hubungan \\
9 & Kebiasaan menggunakan Repellent & 0,280 & 2,140 & $0,708-6,251$ & Tidak ada hubungan \\
\hline
\end{tabular}

Hubungan Jenis TPA dengan kejadian DBD

Hasil uji statistik dengan menggunakan Chi-square, diperoleh $p$ value 0,15 , karena $p$ value > 0,05 maka Ho diterima, artinya tidak ada hubungan yang signifikan antara variabel jenis TPA dengan kejadian DBD di Wilayah Kerja Puskesmas Purwokerto Selatan Kabupaten Banyumas Tahun 2016. Nilai Odd Ratio (OR) $0,241(95 \% \mathrm{CI}=0,46-1,259)$, menunjukan bahwa rumah responden yang memiliki kontainer jenis TPA mempunyai risiko 0,241 lebih besar menderita DBD dari pada rumah responden yang memiliki kontainer jenis non TPA.

Jenis TPA yang positf ditemukan jentik pada saat observasi yaitu bak mandi, ember, ban bekas, botol bekas, dan barang bekas. Pada penelitian ini TPA yang paling banyak ditemukan jentik yaitu ember, berbeda dengan penelitian yang dilakukan oleh Zulkarnaini et al. (2009) di Kota Dumai dengan persentase larva yang ditemukan pada drum cukup tinggi, wadah ukuran besar seperti drum dan bak mandi merupakan TPA yang berpotensi sebagai tempat perkembangbiakan nyamuk Aedes aegypti karena ukuran yang besar dan kurang memungkinkan untuk dikuras airnya secara rutin.(Zahara fadilla, 2013)

Perbedaan dari beberapa hasil penelitian diatas dapat disimpulkan bahwa bervariasinya jenis kontainer yang ditemukan tergantung lokasi, situasi atau kondisi, kebiasaan dan perilaku masyarakat dalam menggunakan wadah sebagai tempat penampungan air bersih untuk kebutuhan sehari-hari.

Menurut Sitio anton (2008) keberadaan kontainer sangat berperan dalam kepadatan jentik Aedes, karena semakin banyak kontainer akan semakin banyak tempat perindukan dan akan semakin padat populasi nyamuk Aedes. Semakin padat populasi nyamuk Aedes, maka semakin tinggi pula risiko terinfeksi virus DBD dengan waktu penyebaran lebih cepat sehingga jumlah kasus penyakit DBD cepat meningkat yang pada akhirnya mengakibatkan terjadinya KLB penyakit DBD.
Menurut Juli Soemirat Slamet (2009, h. 101) nyamuk Aedes suka bersarang di air bersih. Tempat - tempat yang dapat dijadikan sarang banyak sekali, mulai daru jambangan bunga, kaleng - kaleng ataupun potongan bambu yang terisi air hujan, sampai pada reservoir air bersih yang tidak tertutup.

\section{Hubungan warna TPA dengan kejadian DBD}

Hasil uji statistik dengan menggunakan Chi-square, diperoleh $p$ value 0,624, karena $p$ value $>0,05$ maka Ho diterima, artinya tidak ada hubungan yang signifikan antara variabel warna TPA dengan kejadian DBD di Wilayah Kerja Puskesmas Purwokerto Selatan Kabupaten Banyumas Tahun 2016. Nilai Odd Ratio $(O R)=$ $1,436(95 \% \mathrm{CI}=0,547-3,770)$, menunjukan bahwa rumah responden yang memiliki TPA dengan warna gelap mempunyai risiko 1,436 kali lebih besar menderita DBD dari pada rumah responden yang memiliki TPA dengan warna terang.

Hasil penelitian ini sesuai dengan penelitian eksperimental yang dilakukan oleh Sungkar (1994) yang dikutip oleh Nita Prasasti (2013), menunjukan bahwa kepadatan larva pada TPA yang berwarna gelap lebih tinggi dibandingkan TPA berwarna terang. Pada TPA yang gelap akan memberikan rasa aman dan tenang waktu bertelur, sehingga telur yang diletakan lebih banyak dan jumlah larva yang terbentuk juga lebih banyak. Semakin banyak telur yang diletakan, maka semakin banyak pula jumlah jentik yang terbentuk. Selain itu, suasana gelap menyebabkna jentik menjadi tidak terlihat sehingga tidak bisa diciduk atau dibersihkan

\section{Hubungan keberadaan tanaman sekitar rumah dengan kejadian DBD}

Hasil uji statistik dengan menggunakan Chi-square, diperoleh $p$ value 1,00 , karena $p$ value $>0,05$ maka Ho diterima, artinya tidak ada hubungan yang signifikan antara variabel keberadaan tanaman sekitar rumah dengan kejadian DBD di Wilayah Kerja Puskesmas Purwokerto Selatan Kabupaten Banyumas Tahun 2016. Nilai Odd Ratio $(O R)=1,210(95 \% \mathrm{CI}=$ 
0,360 - 4,065), menunjukan bahwa responden yang memiliki tanaman disekitar rumah mempunyai risiko 1,210 kali lebih besar menderita DBD dari pada responden yang tidak memiliki tanaman disekitar rumah.

Menurut penelitian yang dilakukan oleh Fauzan ma'ruf (2011) di Kabupaten Banyumas, variabel keberadaan tanaman disekitar rumah diperoleh $\mathrm{p}=0,713$ artinya tidak ada hubungan antara keberadaan tanaman disekitar rumah dengan kejadian DBD di Kabupaten Banyumas.

Adanya tumbuh - tumbuhan sangat mempengaruhi kehidupan nyamuk antara lain sebagai tempat meletakan telur, tempat berlindung, tempat mencari makan dan berlindung bagi jentik dan tempat hinggap istirahat nyamuk dewasa selama menunggu siklus gonotropik. Selain itu adanya suatu jenis tumbuhan atau berbagai jenis tumbuhan pada suatu tempat dapat dipakai sehingga indikator memperkirakan adanya jenis - jenis nyamuk tertentu (Ditjen PP \& PL, 2007, h. 11).

\section{Hubungan ventilasi dengan kejadian DBD}

Hasil uji statistik dengan menggunakan Chi-square, diperoleh $p$ value 0,734, karena $p$ value > 0,05 maka Ho diterima, artinya tidak ada hubungan yang signifikan antara variabel ventilasi dengan kejadian DBD di Wilayah Kerja Puskesmas Purwokerto Selatan Kabupaten Banyumas Tahun 2016. Nilai Odd Ratio $(O R)=$ 1,607 (95\% CI $=0,410-6,229)$, menunjukan bahwa rumah yang tiadak ada kawat kasa pada ventilasi mempunyai risiko 1,607 kali lebih besar menderita DBD dari pada rumah responden yang dipasang kawat kasa pada ventilasi.

Berdasarkan data yang telah diperoleh, sebagian besar responden belum ada kawat kasa pada ventilasi. Hal ini dimungkinkan karena bagi responden yaitu masyarakat di wilayah kerja Puskesmas Purwokerto Selatan Kabupaten Banyumas pemasangan kawat kasa belum menjadi kebiasaan atau belum dirasakan sebagai kebutuhan dalam rangka mencegah masuknya nyamuk kedalam rumah, oleh karena itu perlu adanya penyuluhan guna meningkatkan pengetahuan masyarakat akan pentingnya memasang kawat kasa pada ventilasi sebagai salah satu usaha dalam rangka mengurangi masuknya nyamuk kedalam rumah responden sehingga dapat terhindar dari gigitan nyamuk.

Rumah dengan kondisi ventilasi tidak terpasang kasa nyamuk atau strimin, akan memudahkan nyamuk untuk masuk ke dalam rumah untuk menggigit manusia dan untuk beristirahat. Keadaan ventilasi rumah yang tidak ditutupi kawat kasa akan menyebabkan nyamuk masuk kedalam rumah. Dengan tidak adanya kasa nyamuk pada ventilasi rumah,akan memudahkan nyamuk Aedes aegypti masuk ke dalam rumah pada pagi hingga sore hari. Hal ini tentunya akan memudahkan terjadinya kontak antara penghuni rumah dengan nyamuk penular Demam Berdarah Dengue (DBD), sehingga akan meningkatkan risiko terjadinyapenularan DBD yang lebih tinggi dibandingkan dengan rumah yang ventilasinya terpasang kasa. (Riza Berdian Tamza, 2013)

\section{Hubungan mobilitas dengan kejadian DBD}

Hasil uji statistik dengan menggunakan Chi-square, diperoleh $p$ value 0,620 , karena $p$ value $>0,05$ maka Ho diterima, artinya tidak ada hubungan yang signifikan antara variabel mobilitas dengan kejadian DBD di Wilayah Kerja Puskesmas Purwokerto Selatan Kabupaten Banyumas Tahun 2016. Nilai Odd Ratio $(O R)=$ $1,447$ (95\% CI $=0,545-3,842)$, menunjukan bahwa responden yang melakukan mobilitas mempunyai risiko 1,447 kali lebih besar menderita DBD dari pada responden yang tidak melakukan mobilitas.

Menurut pendapat Sunaryo yang dikutip oleh Arda Dinata (2012) mobilitas penduduk memudahkan penularan dari satu tempat ke tempat lainnya dan biasanya penyakit menjalar dimulai dari suatu pusat sumber penularan kemudian mengikuti lalu lintas penduduk. Makin ramai lalu lintas itu, makin besar kemungkinan penyebaran.

Dalam studi ini, tempat-tempat umum yang terdekat dengan rumah responden adalah sekolah, terminal, pasar dan tempat ibadah. Terminal merupakan unit fasilitas untuk pelayanan umum, dalam hal ini pergerakan manusia dan barang dari satu tempat ke tempat lain sehingga terminal cukup berpengaruh dengan kejadian DBD karena kemungkinan untuk terjadinya pertukaran tipe virus dengue sangat besar, selain itu banyak orang yang datang dari berbagai daerah/wilayah, kemungkinan adanya penderita atau carrier yang membawa tipe dengue yang berlainan sesuai dengan lokasi asal. Dengan demikian penularan DBD kemungkinan dapat terjadi selain dirumah dapat juga di sekolah atau tempat-tempat umum lainnya.

\section{Hubungan kebiasaan menggantung pakaian dengan kejadian DBD}

Hasil uji statistik dengan menggunakan Chi-square, diperoleh $p$ value 0,033 , karena $p$ value < 0,05 maka Ho ditolak, artinya ada hubungan yang signifikan antara variabel kebiasaan menggantung pakaian dengan kejadian DBD di Wilayah Kerja Puskesmas Purwokerto Selatan Kabupaten Banyumas Tahun 2016. Nilai Odd Ratio $(O R)=4,942(95 \%$ CI $=1,236-$ 19,750), menunjukan bahwa responden yang memiliki kebiasaan menggantung pakaian mempunyai risiko 4,942 kali lebih besar menderita DBD dari pada responden yang tidak memiliki kebiasaan menggantung pakaian.

Penelitian yang sejalan dengan penellitian ini yaitu penelitian yang dilakukan oleh Teguh 
Widyanto (2007) analisa statistik mendapatkan nilai $\mathrm{p}=0,014$ yang menunjukkan bahwa ada hubungan yang bermakna secara statistik antara kebiasaan menggantung baju dengan kejadian DBD di kota Purwokerto. Menurut Isnawanty kunji (2013) hal ini merupakan faktor yang berpengaruh terhadap penyakit DBD, karena salah satu tempat kebiasaan nyamuk istirahat itu ada pada pakaian yang bergantungan

Menurut Teguh Widyanto (2007) Keberadaan nyamuk untuk hinggap istirahat selama menunggu waktu bertelur dan tempat tersebut gelap, lembap dan sedikit angin, dan nyamuk tersebut biasa hinggap dan menempel dipakaian di dalam rumah. Pakaian merupakan kebutuhan sandang bagi setiap manusia yang keberadaannya tidak pernah lepas dari kehidupan manusia. Namun, penanganan pakaian setelah digunakan seringkali diabaikan. Seperti halnya kebiasaan menggantung pakaian dapat menyebabkan jumlah nyamuk di dalam rumah bertambah karena seringkali nyamuk lebih senang hinggap pada pakaian yang menggantung. (Ardha dinata, 2011)

\section{Hubungan kebiasaan Tidur siang dengan kejadian DBD}

Hasil uji statistik dengan menggunakan Chi-square, diperoleh $p$ value 0,222, karena $p$ value $>0,05$ maka Ho diterima, artinya tidak ada hubungan yang signifikan antara variabel kebiasaan tidur siang dengan kejadian DBD di Wilayah Kerja Puskesmas Purwokerto Selatan Kabupaten Banyumas Tahun 2016. Nilai Odd Ratio $(O R)=2,063(95 \% \mathrm{CI}=0,779-5,461)$, menunjukan bahwa responden yang memiliki kebiasaan tidur siang mempunyai risiko 2,063 kali lebih besar menderita DBD dari pada responden yang tidak memiliki kebiasaan tidur siang.

Menurut Penelitian Dardjito dkk (2008) yang dilakukan di Kecamatan Purwokerto Timur diperoleh $\mathrm{p}=0,444$ yang menunjukan tidak ada hubungan antara kebiasaan tidur siang dengan kejadian DBD. Penelitian yang dilakukan oleh pramudyo, dkk (2015) diperoleh $\mathrm{p}=1,00$ artinya tidak ada hubungan antara kebiasaan tidur siang dengan kejadian DBD.

Berdasarkan data yang diperoleh, sebagian besar masyarakat di Wilayah Kerja Puskesmas Purwokerto Selatan melakukan aktivitas pada siang hari, karena kasus tertinggi berada pada rentang umur 11 - 20 tahun, artinya banyak responden yang melakukan aktivitas seperti sekolah maupun bekerja sehingga banyak yang tidak mempunyai kebiasaan tidur siang. Orang yang memiliki kebisaan tidur siang mempunyai risiko 2,063 kali lebih besar dibandingkan orang yang tidak biasa tidur siang,karena kebiasaan nyamuk Aedes aegypti yaitu pagi hingga sore hari, yaitu pada 08.00 - pukul 12.00 dan 17.00 dan lebih banyak menggigit di dalam rumah dari pada diluar rumah. Nyamuk ini sangat ini sangat menyenangi darah manusia dan bisa menggigit beberapa kali (Ditjen PP \& PL, 2007, h. 5)

Kebiasaan menggunakan repellent dengan kejadian DBD

Hasil uji statistik dengan menggunakan Chi-square, diperoleh $p$ value 0,280, karena $p$ value $>0,05$ maka Ho diterima, artinya tidak ada hubungan yang signifikan antara variabel kebiasaan menggunakan repellentt dengan kejadian DBD di Wilayah Kerja Puskesmas Purwokerto Selatan Kabupaten Banyumas Tahun 2016. Nilai Odd Ratio $(O R)=2,104(95 \%$ CI $=$ 0,708 - 6,251), menunjukan bahwa responden yang tidak memliki kebiasaan menggunakan repellentt mempunyai risiko 2,104 kali lebih besar menderita DBD dari pada responden yang memiliki kebisaan menggunakan repellent.

Dilihat dari banyaknya jumlah hasil presentasi kebiasaan tidak menggunakan obat anti nyamuk ini merupakan salah satu faktor yang berpengaruh terhadap penyakit DBD, hal ini dikarenakan oleh tingkat kesadaran masyarakat tentang tindakkan pencegahan gigitan nyamuk itu kebanyakan hanya pada malam hari, mereka tidak menyadari bahwa aktivitas nyamuk Aedes aegypti pada pagi hari (pukul 09.00-10.00) dan sore hari (pukul 16- 17.00). Berbeda dengan responden yang masih balita pada saat tidur siang hari orang tuanya memberikan perlindungan terhadap gigitan nyamuk dengan menyalakan obat nyamuk. Dan untuk sebagian penderita yang didapatkan memiliki kebiasaan menggunakan obat anti nyamuk pada pagi hari dan sore hari tetapi tetap menderita DBD ini dikarenakan faktor lain, yaitu faktor keberadaan jentik dan kebiasaan menggantung.

\section{Analisis Multivariat}

Tabel 4 Analisis Multivariat

\begin{tabular}{lccl}
\hline $\begin{array}{l}\text { Variabel } \\
\text { Independent }\end{array}$ & $\mathrm{P}$ & $\mathrm{B}$ & $\mathrm{CI}(95 \%)$ \\
\hline $\begin{array}{l}\text { Jenis TPA } \\
\text { Kebiasaan } \\
\text { menggantung } \\
\text { pakaian }\end{array}$ & 0,088 & 0,197 & $0,31-1,684$ \\
$\begin{array}{l}\text { Kebiasaan } \\
\text { tidur siang }\end{array}$ & 0,080 & 2,667 & $0,889-7,997$ \\
\hline
\end{tabular}

Tabel 4 menunjukan bahwa hubungan variabel dengan kejadian DBD yang berpengaruh atau besar adalah variabel kebiasaan menggantung pakaian ( $\mathrm{p}=0,011$ ) yang disusul dengan varibel kebiasaan tidur siang $(\mathrm{p}=0,080)$, jenis TPA ( $p=0,088)$ dan keberadaan jentik pada kontainer. Variabel yang paling berpengaruh yaitu kebiasaan menggantung pakaian dengan nilai $\mathrm{p}=0,011$

Sesuai dengan pendapat yang disampaikan Widodo (2002) yang dikutip oleh Jasrida yunita (2012) bahwa pakaian yang manggantung dalam ruangan merupakan tempat yang disenangi nyamuk Aedes aegypti untuk beristirahat setelah 
menghisap darah manusia. Setelah beristirahat pada saatnya akan menghisap darah manusia kembali sampai nyamuk tersebut cukup darah untuk pematangan sel telurnya. Jika nyamuk yang beristirahat pada pakaian menggantung tersebut menghisap darah penderita demam berdarah dan selanjutnya pindah dan menghisap darah orang yang sehat maka dapat tertular virus demam berdarah dengue.

Hasil analisis tersebut menunjukan responden yang masih memiliki kebiasaan menggantung pakaian memiliki peluang untuk bisa terkena penyakit DBD dari pada responden yang tidak memiliki kebiasaan menggantung pakaian. Seharusnya pakaian-pakaian yang tergantung di balik lemari atau di balik pintu sebaiknya dilipat dan disimpan dalam almari, karena nyamuk Aedes aegypti senang hinggap dan beristirahat di tempat-tempat gelap dan kain yang tergantung . Tempat istirahat yang disukai nyamuk adalah benda-benda yang tergantung di dalam rumah seperti gorden, kelambu dan pakaian.

\section{Simpulan dan saran} Simpulan

Hasil analisis bivariat diketahui ada hubungan antara kebiasaan menggantung pakaian $(\mathrm{p}=0,33)$ dengan kejadian DBD di Wilayah Kerja Puskesmas Purwokerto Selatan Kabupaten Banyumas Tahun 2016. Analisis multivariat diketahui kebiasaan menggantung pakaian berpengaruh dengan kejadian DBD ( $\mathrm{p}=0,018)$. Saran

Meningkatkan promosi kesehatan kepada masyarakat tentang cara mencegah DBD agar masyarakat sadar dalam memperhatikan kesehatan di sekitar lingkungan rumahnya terutama melaksanakan $3 \mathrm{M}$ plus, dan memperbaiki kondisi rumah yang berisiko terhadap penyakit DBD seperti memasang kawat kasa pada ventilasi.

\section{Ucapan Terimakasih}

Terima kasih disampaikan kepada Puskesmas Purwokerto Selatan dan Jurusan Kesehatan LingkunganPoliteknik Kesehatan Kemenkes Semarang, sehingga penelitian dapat terselesaikan.

\section{Daftar Pustaka}

Anif Budiyanto, 2012, Perbedaan Warna Kontainer Berkaitan dengan Keberadaan Jentik Aedes aegypti di Sekolah Dasar, Loka Litbang P2B2 Baturaja.

Ardha Dinata, dkk, 2012, Karakteristik Lingkungan Fisik, Biologi, dan Sosial di Daerah Endemis DBD kota Banjar tahun 2011, Jurnal Ekologi Kesehatan: Vol. 11 No 4.
Aryu Chandra, 2010, Demam Berdarah Dengue : Epidemiologi, Patogenesis, dan Faktor risiko Penularan, Aspirator Vol. 2 No. 2 Tahun 2010 : 110-119.

Akhsin Zukoni, 2010, Parasitologi, Yogyakarta : Anggota IKAPI.

Arcole, Magatan, 1996, Mewaspadai Demam Berdarah dan Berbagai Macam Demam Lainnya, Solo: Toko Buku Agency.

Cecep Dani Sucipto, 2011, Vektor Penyakit Tropis. Yogyakarta: Gosyen Publishing.

Departemen Kesehatan R.I, Direktorat Jenderal Pengendalian Penyakit dan Penyehatan Lingkungan (DIT . JEN. PP \& PL), 2007 a, Survai Entomologi Demam Berdarah Dengue, Jakarta : DIT .JEN. PP \& PL. ),2007 b, Ekologi dan Aspek Perilaku Vektor, Jakarta : DIT .JEN. PP \& PL.

Endo Dardjito, dkk, Beberapa Faktor Risiko yang Berpengaruh Terhadap Kejadian Penyakit Demam Berdarah Dengue (DBD) di Kabuapaten Banyumas, Jurnal : Media Litbang Kesehatan Volume XVIII Nomor 3 Tahun $2008: 126$ - 136.

Fauzan Ma'aruf, 2011, Hubungan Lingkungan dengan Kejadian Penyakit Demam Berdarah Dengue (DBD) di Kabupaten Banyumas tahun 2011, Purwokerto : Kemenkes RI Politeknik Kesehatan Semarang Jurusan Kesehatan Lingkungan Purwokerto

Genis Ginanjar, 2007, Apa yang Dokter Anda Tidak Katakan Tentang Demam Berdarah Edisi 1, Bandung : Bintang Pustaka.

Isnawanty Kundji, 2013, Deskripsi Faktor-Faktor Yang Mempengaruhi Penderita Penyakit Demam Berdarah Dengue (Dbd) Di Wilayah Kerja Puskesmas Telaga Biru Kecamatan Telaga Biru Kabupaten Gorontalo, Jurusan Kesehatan Masyarakat Fakultas Ilmu-Ilmu Kesehatan Dan Keolahragaan Universitas Negeri Gorontalo

Jasrida yunita, dkk, 2012, Pengaruh Perilaku Masyarakat Dan Kondisi Lingkungan Terhadap Kejadian Demam Berdarah Dengue (DBD), Jurnal Kesehatan Komunitas, Vol. 1 No. 4 Mei 2012 : 193 198

Juli Soemirat Slamet, 2009, Kesehatan Ligkungan, Yogyakarta : Gadjah Mada University Press.

Kementerian Kesehatan Indonesia, 2014, Modul Pengendalian Demam Berdarah Dengue, Jakarta : Kementerian Kesehatan RI.

Mustazahid Agfadi Wirayoga, 2013, Hubungan Kejadian Demam Berdarah Dengue Dengan Iklim di Kota Semarang Tahun 2011 - 2016, Semarang : Universitas 
Negeri Semarang Jurusan Kesehatan Masyarakat

Nita Prasasti, 2013, Asosiasi antara jenis tempat penampungan air dan Kejadian Demam Berdarah Dengue di Wilayah Kota Surakarta,

(http://jurnal.fk.uns.ac.id/index.php/NexusKedokteran-Komunitas/article/view/256, diakses 16 Juni 2015 pukul 11.22)

Pramudiyo Teguh Sucipto, dkk, 2015, Faktor Faktor Yang Mempengaruhi Kejadian Penyakit Demam Berdarah Dengue (DBD) dan Jenis Serotipe Virus Dengue Di Kabupaten Semarang, Jurnal Kesehatan Lingkungan Indonesia Vol. 14 No. 2/ Oktober Tahun 2015 : 51 - 56

Riza Berdian Tamza, 2013, Hubungan Faktor Lingkungan dan Perilaku dengan Kejadian Demam Berdarah Dengue (DBD) di Wilayah Kelurahan Perumnas Way Halim Kota Bandar Lampung, Jurnal Kesehatan Masyarakat Volume 2 Nomor 2 April Tahun 2013.

Sembel, T.D, 2009, Entomologi Kedokteran, Jogjakarta : Andi

Shinta Kusumaningtyas, 2011, Hubungan Kondisi Fisik dan Keberadaan Jentik Aedes aegypti dalam kontainer Kejadian Dengue Haemmorhagic Fever (DHF) di Wilayah Kerja Puskesmas Blora, (http://eprints.undip.ac.id/32791/, diakses 29 Desember 2015 pukul 19.25)

Sitio Anton, 2008, Hubungan Perilaku Tentang Pemberantasan Sarang Nyamuk Dan Kebiasaan Keluarga Dengan Kejadian Demam Berdarah Dengue Di Kecamatan Medan Perjuangan Kota Medan Tahun 2008, Semarang : Universitas Diponegero

Soedarto, 2009, Penyakit Menular di Indonesia. Jakarta : Sagung Seto.

Soedarto, 2003, Zoonosis Kedokteran, Surabaya : Airlangga University Press.

Soegeng Soegijanto, 2006, Demam Berdarah Dengue Edisi 2, Surabaya: Airlangga University Press.
Sofia, dkk, 2014, Hubungan Kondisi Lingkungan Rumah dan Perilaku Keluarga dengan Kejadian Demam Berdarah Dengue Di Kabupaten Aceh Besar, Jurnal Kesehatan Lingkungan Indonesia Vol. 13 No. 1 / April $2014 \quad: \quad 30 \quad-38$. (http://etd.eprints.ums.ac.id/5966/1/J41005 0022.PDF, di akses 13 Juni pukul 16.31)

Sutaryo, 2005, Dengue, Yogyakarta : Medika FK UGM.

Wahyu Mahardika, 2009, Hubungan antara Perilaku Kesehatan dengan Kejadian Demam Berdarah Dengue (DBD) di Wilayah Kerja Puskesmas Cepiring Kecamatan Cepiring Kabupaten Kendal Tahun 2009, Semarang : Universitas Negeri Semarang.

Widia Eka Wati, 2009, Beberapa Faktor Yang Berhubungan Dengan Kejadian Demam Berdarah Dengue (DBD) Di Kelurahan Ploso Kecamatan Pacitan Tahun 2009, (http://etd.eprints.ums.ac.id/5966/1/J41005 0022.PDF, di akses 13 Juni pukul 16.31)

Widiyono, 2008, Penyakit Tropis Epidemiologi, Penularan, Pencegahan \& Pemberantasannya, Jakarta : Erlangga.

Wisfer, dkk, 2014, Hubungan Jumlah Penghuni, Tempat Penampungan Air Keluarga dengan Keeradaan Larva Aedes aegypty di Wilayah Endemis DBD Kota Makasar, Makasar : Fakultas Kesehatan Masyarakat Unhas.

World Health Organization (WHO), 2002, Panduan Lengkap Pencegahan \& Pengendalian \& Demam Berdarah, Jakarta : Buku Kedokteran EGC.

Zahara Fadila, dkk, 2015, Bioekologi vektor demam berdarah dengue (DBD) serta deteksi virus dengue pada Aedes aegypti (Linnaeus) dan Ae. albopictus (Skuse) (Diptera: Culicidae) di kelurahan endemik DBD Bantarjati, Kota Bogor, Jurnal Entomologi indonesia Vol. 12 No. 1 Maret Tahun $2015: 31-38$ 